\title{
Paclobutrazol Reduces Insecticide Phytotoxicity on Salvia
}

\author{
Joyce G. Latimer ${ }^{1}$ and Ronald D. Oetting ${ }^{2}$ \\ Georgia Experiment Station, The University of Georgia, Griffin, GA 30223
}

Additional index words. bendiocarb, Salvia splendens, growth regulator, plant protection

\begin{abstract}
Four-week-old salvia (Salvia splendens F. Sellow 'Red Pillar') seedlings were treated with 0 or $50 \mathrm{ppm}$ paclobutrazol, followed $5 \mathrm{~h}$ later by $0,1,2$, or 4 times $(0 \times, 1 \times, 2 \times$, or $4 \times$, respectively) the recommended label rate of bendiocarb $(0.6 \mathrm{~g}$ a.i./liter), a carbamate insecticide. Seven days after treatment (DAT), phytotoxicity ratings increased with bendiocarb rate on all plants, but $50 \mathrm{ppm}$ paclobutrazol reduced damage at $1 \times$ and $4 \times$ bendiocarb. Paclobutrazol also improved plant recovery from phytotoxicity damage at 21 DAT. Bendiocarb decreased the height of plants not treated with paclobutrazol at 7, 14, and 21 DAT. Plants treated with $40 \mathrm{ppm}$ paclobutrazol had lower maximum phytotoxicity damage at 14 DAT, and even better recovery at 21 DAT than plants treated with 20 or 60 ppm paclobutrazol. Plants treated with paclobutrazol 4 days before applying bendiocarb had lower maximum phytotoxicity ratings relative to controls than plants treated 8 days before, the same day as, or 4 days after bendiocarb application. Chemical names used: $\beta$ - [(4-chlorophenyl)methyl]- $\alpha$-(1,1-dimethylethyl)-1 $H$ - 1,2,4-triazole-1-ethanol (paclobutrazol); 2,2-dimethyl,1,3-benzodioxol-4-yl-methylcarbamate (bendiocarb).
\end{abstract}

Insecticide phytotoxicity is a problem in ornamental production because of the variety of species and the lack of specific phytotoxicity tests. Phytotoxicity can be exacerbated by growing conditions during plant production [e.g., greenhouse vs. field(Crocker and Brewer, 1987); cultural practices, such as medium $\mathrm{pH}$ (Oetting et al., 1988); growing temperature; irrigation frequency (R.D.O., unpublished data).

Plant growth regulators reduce damage from environmental, chemical, and air pollutant stresses. Applying 1-(4-chlorophenoxy)3,3-dimethyl-1-(1,2,4-triazol-1-yl)-2butanone (triadimefon), a triazole fungicide, 7 days before heat or chilling stress reduced damage to bean (Phaseolus vulgaris L.) seedlings (Asare-Boamah and Fletcher, 1986), Applying butanedioic acid mono(2,2dimethylhyhdrazide) (daminozide) 4 days before exposure to the herbicide 4-amino-6- tertbutyl-3-(methylthio) -as- triazin- 5(4 H) -one (metribuzin) protected potato (Solanum tuberosum L.) seedlings from damage (Phatak et al., 1985), and applying paclobutrazol 2 to 4 days before exposure to $\mathrm{SO}_{2}$ completely protected soybean [Glycine $\max (\mathrm{L}$.) Merr.] plants from damage (Lee et al., 1992). Furthermore, (E)-(p-chlorophenyl)-4,4-dimethyl-2-(1,2,4triazol-1-yl)- 1 -penten-3-ol (uniconazole) ap-

\footnotetext{
Received for publication 10 June 1993. Accepted for publication 19 Oct. 1993. This material is based on work supported by the Cooperative State Research Service, U.S. Dept. of Agriculture, under agreement no. 89-34103-4269. We gratefully acknowledge the assistance of Sherrod Baden and Kenneth Steele. The cost of publishing this paper was defrayed in part by the payment of page charges. Under postal regulations, this paper therefore must be hereby marked advertisement solely to indicate this fact.

Associate Professor, Dept. of Horticulture.

${ }^{2}$ Professor, Dept. of Entomology.
}

plied 7 days before stress not only reduced $\mathrm{SO}_{2}$ damage to cucumber (Cucumis sativus L.) plants, but also improved plant recovery from pollutant stress as measured by recovery of photosynthetic capacity (Upadhyaya et al., 1991).

Other chemicals also protect plants. Using the insecticide $O, O$-diethyl $S$ - [(ethylthio) methyl] phosphorodithioate (phorate) concurrently with the herbicide 2-[(2-chlorophenyl) methyl]-4,4-dimethyl-3-isoxazolidinone (clomazone) protects cotton (Gossypium hirsutum L.) seedlings from herbicide damage (York et al., 1991). In preliminary experiments, there was little phytotoxicity on salvia treated with the insecticide $O, S$ - dimethyl acetylphosphoramidothioate (acephate; Orthene) or potassium salts of fatty acids (insecticidal soap; Safer's Insecticidal Soap), but bendiocarb (Dycarb) caused extensive phytotoxicity (Latimer and Oetting, 1990). Applying paclobutrazol earlier the same day that insecticides were applied reduced the maximum damage caused by insecticides 14 days after treatment (DAT) and improved plant recovery from phytotoxicity 21 DAT.

Our objective was to verify that paclobutrazol can protect salvia, a bedding plant species sensitive to insecticides, from bendiocarb phytotoxicity and to evaluate the effect of paclobutrazol concentration and time of application on this protection.

\section{Materials and Methods}

Plant material and culture. 'Red Pillar' salvia seeds were sown in seedling flats and transplanted $\approx 3$ weeks after sowing. Seedlings grew in plastic cell packs $(3.8 \times 3.8 \times 6.0 \mathrm{~cm}$. In the May 1989 experiment, the cell packs were filled with Pro-Gro 200 (Pro-Gro Products, Elizabeth City, N.C.); in the June 1990 experiments, the cell packs (volume $48 \mathrm{~cm}^{3}$ ) were filled with Metro-Mix Redi-Earth
(Grace-Sierra Horticultural Products, Cambridge, Mass.). We applied treatments 1 week after transplanting. In each experiment, we sprayed paclobutrazol at $1.0 \mathrm{ml} / \mathrm{plant}$ at 0900 HR. Paclobutrazol concentration varied with the experiment. Bendiocarb (Dycarb 76W; Grace-Sierra) was applied as a foliar spray at $0,1,2$, or 4 times $(0 \times, 1 \times, 2 \times$, or $4 \times$, respectively) the recommended label rate of $0.6 \mathrm{~g}$ a.i/ liter. This range of insecticide rates commonly is used to determine an acceptable insecticidal safety margin on a specific species. Bendiocarb rates varied with the experiment.

The treated plants were arranged in a factorial design with four plants per treatment in each of four replications. Plant height and phytotoxicity damage were measured at 7, 14, and 21 DAT. Damage evaluations were based on any observable deviations in the plants that could be attributed to chemical application. We did not discriminate between chemical toxicity and similar damage that occurred because of cultural practices. Therefore, damage ratings of nontreated plants were occasionally $>0$. In the May 1989 experiment, we used a damage scale ( 0 to 5$)$ that, after arcsin transformation, corresponded to $\mathrm{O}=$ no injury to $90=$ severe injury. We used a continuous scale to determine the damage rating in the June 1990 experiments $(0=$ no injury, $100=$ severe injury) wherein a rating on a $10-\mathrm{cm}$ line was measured in millimeters to provide the phytotoxicity rating (Little, 1985). Final growth was measured 28 DAT. Three separate experiments were conducted to determine the influence of paclobutrazol on bendiocarb phytoxicity.

Paclobutrazol vs. insecticide. Salvia seedlings were treated with 0 or $50 \mathrm{ppm}$ paclobutrazol on 11 May 1989; $5 \mathrm{~h}$ after paclobutrazol treatment, the seedlings were treated with bendiocarb at $0 \times, 1 \times, 2 \times$, or $4 \times$ the recommended label rate. The greenhouse averaged 29/17C (day/night) with photosynthetic photon flux (PPF) averaging $20 \mathrm{~mol} \cdot \mathrm{m}^{-1} \cdot \mathrm{day}^{-1}$ during the experiment.

Paclobutrazol rate. In June 1990, salvia seedlings were treated with $0,20,40$, or 60 ppm paclobutrazol 1 week after transplanting into cell packs. After $5 \mathrm{~h}$, we applied bendiocarb at $0 \times, 1 \times, 2 \times$, or $4 \times$ the recommended label rate. We monitored plant-water relations before we applied bendiocarb using a LI-COR 1600 steady-state porometer (LICOR, Lincoln, Neb.). The greenhouse averaged 26/19C (day/night) with PPF averaging $17 \mathrm{~mol} \cdot \mathrm{m}^{-1} \cdot$ day $^{-1}$ during the experiment.

Time of paclobutrazol application. Later in June 1990, paclobutrazol was applied at 0, 20,40 , or $60 \mathrm{ppm}$ to 4 -week-old seedlings at 8 or 4 days before, the same day as ( $5 \mathrm{~h}$ before), or 4 days after bendiocarb application $(0 \times, 1 \times$, or $4 x$ ). Date of paclobutrazol treatment was treated as a main plot with paclobutrazol and bendiocarb treatments arranged in a factorial design within each date. The greenhouse averaged 29/21C (day/night) with PPF averaging $10 \mathrm{~mol} \cdot \mathrm{m}^{-1} \cdot$ day $^{-1}$ during the experiment.

Statistical analysis. We performed an analysis of variance on all data using the general linear models procedure of SAS (Littell et al., 
1991). We separated the effects of insecticide or paclobutrazol rates using single degreeof-freedom contrasts.

\section{Results}

Paclobutrazol vs. insecticide. The phytotoxicity observed on salvia was typical of many insecticides. Bendiocarb is labeled for use on a wide range of bedding plants, including salvia. Salvia, however, is sensitive to insecticide damage. In these experiments, the most common damage caused by bendiocarb exposure was leaf tip necrosis followed by leaf margin necrosis. Applying bendiocarb to terminal growth often resulted in distorted growth as leaves expanded. In more severe cases, leaf tissue thickened, resulting in leathery leaves with a blistered or cupped appearance. Phytotoxicity ratings at 7 DAT increased with bendiocarb rates at both 0 and $50 \mathrm{ppm}$ paclobutrazol (Table 1). Although phytotoxicity was high, $50 \mathrm{ppm}$ paclobutrazol provided slight, but significant, protection from $1 \times$ and $4 \times$ bendiocarb. At 14 DAT, there was little difference in the maximum phytotoxicity between 0 and $50 \mathrm{ppm}$ paclobutrazol at any bendiocarb rate, but paclobutrazol improved plant recovery from the damage. At 21 DAT, the damage ratings of plants treated with 50 ppm paclobutrazol were much lower than controls for all bendiocarb application rates.

Paclobutrazol and bendiocarb each decreased plant height in the May 1989 experiment (Table 2). Bendiocarb reduced the height of plants not treated with paclobutrazol at 7 , 14 , and 21 DAT. Although bendiocarb caused reductions in height of plants treated with 50 ppm paclobutrazol at 7 DAT, reductions in plant height because of paclobutrazol (0 vs. 50 ppm paclobutrazol at $0 \times$ bendiocarb) were not evident until 14 DAT. Bendiocarb did not reduce height of paclobutrazol-treated plants at 14 or 21 DAT. Consequently, the height of control plants treated with $4 \times$ bendiocarb was similar to that of plants treated with $50 \mathrm{ppm}$ paclobutrazol at any bendiocarb rate.

At 28 DAT, $50 \mathrm{ppm}$ paclobutrazol at $0 \times$ bendiocarb reduced all measured growth characteristics except root dry weight (Table 3). Plants not protected by paclobutrazol had reductions in final leaf area and dry weight, and stem length at all bendiocarb rates. However, paclobutrazol did not provide enough protection to prevent further reductions in final leaf area and leaf dry weight at $4 \times$ bendiocarb. Consistent with plant height 21 DAT (Table 2 ), final stem length of paclobutrazol-treated plants was not affected further by bendiocarb rate. Stem dry weight responded in the same manner as stem length (data not presented). Shoot dry weight of plants not treated with paclobutrazol was reduced by all bendiocarb rates, but only $4 \times$ bendiocarb caused further reductions in shoot dry weight of plants treated with paclobutrazol. Root dry weight was not affected by paclobutrazol but was reduced by increasing bendiocarb rates. Paclobtrtrazol did not protect root growth from insecticide effects.

Paclobutrazol rate. Paclobutrazol did not affect stomatal conductance of salvia plants 4 $\mathrm{h}$ after treatment (data not presented). Because there were no statistical interactions between

Table 1. Effect of paclobutrazol (Paclo) on bendiocarb (Bendio) phytotoxicity ratings of salvia plants at 7 , 14 , or 21 days after treatment (DAT). Bendio was applied at $0,1,2$, or 4 times $(0 \times, 1 \times, 2 \times, 4 \times$, respectively) the recommended label rate $5 \mathrm{~h}$ after Paclo treatment.

\begin{tabular}{|c|c|c|c|c|c|c|}
\hline \multirow[b]{4}{*}{ Bendio rate } & \multicolumn{6}{|c|}{ Phytotoxicity damage $^{2}$} \\
\hline & \multicolumn{2}{|c|}{$7 \mathrm{DAT}$} & \multicolumn{2}{|c|}{$14 \mathrm{DAT}$} & \multicolumn{2}{|c|}{$21 \mathrm{DAT}$} \\
\hline & \multicolumn{2}{|c|}{ Paclo (ppm) } & \multicolumn{2}{|c|}{ Paclo (ppm) } & \multicolumn{2}{|c|}{ Paclo (ppm) } \\
\hline & 0 & 50 & 0 & 50 & 0 & 50 \\
\hline $0 x$ & 0 & $0^{\text {syy }}$ & 0 & $0^{\text {ss }}$ & 9 & $0^{* * x}$ \\
\hline $1 x$ & 27 & $18^{* * *}$ & 27 & $23^{* *}$ & 32 & $2^{* * *}$ \\
\hline $2 x$ & 45 & $45^{\mathrm{Ns}}$ & 45 & $41^{\text {Ns }}$ & 32 & $6^{* * *}$ \\
\hline $4 \times$ & 90 & $81^{* * *}$ & 80 & $81^{\mathrm{Ns}}$ & 43 & $28^{* *}$ \\
\hline Significance & $* * *$ & $* * *$ & $* * *$ & $* * *$ & $* * *$ & $* * *$ \\
\hline \multicolumn{7}{|l|}{ Contrasts } \\
\hline $0 \times$ vs. $1 \times$ & $* * *$ & $* * *$ & $* * *$ & $* * *$ & $* * *$ & NS \\
\hline $0 \times$ vs. $2 x$ & $* * *$ & $* * *$ & $* * *$ & $* * *$ & *** & NS \\
\hline $0 x$ vs. $4 x$ & $* * *$ & $* * *$ & $* * *$ & $* * *$ & $* * *$ & $* * *$ \\
\hline Paclo $\times$ Bendio & $* * *$ & & NS & & $* * *$ & \\
\hline
\end{tabular}

${ }^{2}$ Phytotoxicity ratings subjected to arcsin transformation for analysis and presentation. Transformed scale $0=$ no damage to $90=$ severe damage.

'Significance of paclobutrazol treatment.

${ }_{N s,{ }^{* *}, * * *}^{*}$ Nonsignificant or significant at $P \leq 0.01$ or 0.001 , respectively.

Table 2. Effect of paclobutrazol (Paclo) and bendiocarb (Bendio) on salvia plant height at 7, 14, or 21 days after treatment (DAT). Bendio was applied at $0,1,2$, or 4 times $(0 \times, 1 \times, 2 \times, 4 \times$, respectively) the recommended label rate $5 \mathrm{~h}$ after Paclo treatment.

\begin{tabular}{|c|c|c|c|c|c|c|}
\hline \multirow[b]{4}{*}{ Bendio rate } & \multicolumn{6}{|c|}{ Plant ht (cm) } \\
\hline & \multicolumn{2}{|c|}{7 DAT } & \multicolumn{2}{|c|}{14 DAT } & \multicolumn{2}{|c|}{$21 \mathrm{DAT}$} \\
\hline & \multicolumn{2}{|c|}{$\overline{\text { Paclo (ppm) }}$} & \multicolumn{2}{|c|}{ Paclo (ppm) } & \multicolumn{2}{|c|}{ Paclo (ppm } \\
\hline & 0 & 50 & 0 & 50 & 0 & 50 \\
\hline $0 \times$ & 4.0 & $3.6^{\mathrm{NSZ}}$ & 5.9 & $4.6^{*+*}$ & 8.3 & $5.6^{*+*}$ \\
\hline $1 \times$ & 3.8 & $3.3^{*}$ & 5.5 & $4.6^{* *}$ & 7.2 & $5.8^{* * *}$ \\
\hline $2 x$ & 3.7 & $3.3^{\mathrm{Ns}}$ & 5.5 & $4.9^{*}$ & 7.2 & $6.0^{*}$ \\
\hline $4 x$ & 3.1 & $3.2^{\mathrm{Ns}}$ & 4.3 & $4.4^{\mathrm{Ns}}$ & 5.8 & $6.3^{\mathrm{Ns}}$ \\
\hline Significance & $* * *$ & $* * *$ & $* * *$ & NS & $* * *$ & NS \\
\hline \multicolumn{7}{|l|}{ Contrasts } \\
\hline $0 \times$ vs. $1 \times$ & NS & $* *$ & * & NS & $* *$ & NS \\
\hline $0 x$ vs. $2 x$ & $*$ & * & * & NS & $* *$ & NS \\
\hline $0 \times$ vs. $4 \times$ & $* * *$ & $* *$ & $* * *$ & NS & $* * *$ & NS \\
\hline Paclo $\times$ Bendio & NS & & $*$ & & $* *$ & \\
\hline
\end{tabular}

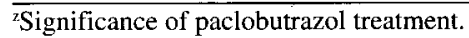

${ }_{N s,+* * *, * * *}$ Nonsignificant or significant at $P \leq 0.05,0.01$, or 0.001 , respectively.

Table 3. Effect of paclobutrazol (Paclo) and bendiocarb (Bendio) on growth measurements of salvia plants at 28 days after treatment. Bendio was applied at 0,1 , 2 , or 4 times $(0 \times, 1 \times, 2 \times, 4 \times$, respectively) the recommended label rate $5 \mathrm{~h}$ after Paclo treatment.

\begin{tabular}{|c|c|c|c|c|c|c|c|c|c|c|}
\hline \multirow[b]{3}{*}{ Bendio rate } & \multirow{2}{*}{\multicolumn{2}{|c|}{$\begin{array}{c}\begin{array}{c}\text { Leaf area } \\
\left(\mathrm{cm}^{2}\right)\end{array} \\
\text { Paclo }(\mathrm{ppm}) \\
\end{array}$}} & \multirow{2}{*}{\multicolumn{2}{|c|}{$\begin{array}{c}\begin{array}{c}\text { Leaf dry wt } \\
(\mathrm{mg})\end{array} \\
\text { Paclo (ppm) }\end{array}$}} & \multirow{2}{*}{\multicolumn{2}{|c|}{$\begin{array}{l}\text { Stem length } \\
(\mathrm{cm}) \\
\text { Paclo (ppm) } \\
\end{array}$}} & \multirow{2}{*}{\multicolumn{2}{|c|}{$\begin{array}{l}\begin{array}{l}\text { Shoot dry wt } \\
(\mathrm{mg})\end{array} \\
\text { Paclo (ppm) } \\
\end{array}$}} & \multirow{2}{*}{\multicolumn{2}{|c|}{$\begin{array}{c}\text { Root dry wt } \\
(\mathrm{mg})\end{array}$}} \\
\hline & & & & & & & & & & \\
\hline & 0 & 50 & 0 & 50 & 0 & 50 & 0 & 50 & 0 & 50 \\
\hline $0 x$ & 136 & $89^{* * * 7}$ & 517 & $413^{* * *}$ & 14.9 & $7.4^{* * *}$ & 721 & $515^{* * *}$ & 335 & $308^{\mathrm{NS}}$ \\
\hline $1 x$ & 117 & $93^{* * *}$ & 422 & $361^{* *}$ & 12.2 & $8.1^{* * *}$ & 564 & $470^{* * *}$ & 248 & $247^{\mathrm{Ns}}$ \\
\hline $2 x$ & 116 & $93^{* * *}$ & 399 & $374^{\mathrm{NS}}$ & 12.3 & $7.9^{* * *}$ & 539 & $474^{*}$ & 244 & $226^{\mathrm{NS}}$ \\
\hline $4 \times$ & 79 & $79^{\mathrm{ss}}$ & 194 & $236^{\mathrm{Ns}}$ & 10.8 & $7.8^{* * *}$ & 267 & $324^{*}$ & 104 & $113^{\mathrm{Ns}}$ \\
\hline Significance & $* * *$ & $* *$ & $* * *$ & $* * *$ & $* * *$ & NS & $* * *$ & $* * *$ & $* * *$ & $* * *$ \\
\hline \multicolumn{11}{|l|}{ Contrasts } \\
\hline $0 \times$ vs. $1 \times$ & $* * *$ & NS & $* * *$ & $*$ & $* * *$ & NS & $* * *$ & NS & $* * *$ & $* * *$ \\
\hline $0 \times$ vs. $2 \times$ & $* * *$ & NS & $* * *$ & NS & $* * *$ & NS & $* * *$ & NS & $* * *$ & $* * *$ \\
\hline $0 \times$ vs. $4 \times$ & $* * *$ & $*$ & $* * *$ & $* * *$ & $* * *$ & NS & $* * *$ & $* * *$ & $* * *$ & $* * *$ \\
\hline Paclo $\times$ Bendio & $* *$ & & $* *$ & & $* *$ & & $* * *$ & & NS & \\
\hline
\end{tabular}

${ }^{\mathrm{z}}$ Significance of paclobutrazol treatment.

ss. *.**.*** Nonsignificant or significant at $P \leq 0.05,0.01$, or 0.001 , respectively. 
paclobutrazol and bendiocarb rates, phytotoxicity ratings are presented for main effects only (Table 4). Paclobutrazol at 20,40, or 60 ppm reduced maximum phytotoxicity on salvia at 14 DAT. Damage caused by bendiocarb increased with bendiocarb rate. Maximum protection from insecticide phytotoxicity due to an excessive (4x) dose of bendiocarb was conferred by 40 ppm paclobtrtrazol (Table 5). Plants treated with $40 \mathrm{ppm}$ paclobutrazol had the lowest maximum damage at 14 DAT and showed greater recovery 21 DAT than plants treated with 20 or 60 ppm paclobutrazol.

Time of paclobutrazol application. Date of paclobutrazol application significantly interacted with paclobutrazol and insecticide effects on plant height and phytotoxicity ratings. Also, the paclobutrazol $\times$ bendiocarb interactions were significant. Salvia response to paclobutrazol at $0 \times$ bendiocarb was consistent with the previous rate experiment (data not presented). Although paclobutrazol generally

Table 4. Main effects of paclobutrazol (Paclo) or bendiocarb (Bendio) (pooled across Bendio or Paclo rates) on phytotoxicity ratings of salvia plants at 7, 14, or 21 days after treatment (DAT). Bendio was applied at $0,1,2$, or 4 times $(0 \times, 1 \times$, $2 \times, 4 \times$, respectively) the recommended label rate $5 \mathrm{~h}$ after Paclo treatments,

\begin{tabular}{lccc}
\hline & \multicolumn{3}{c}{ Phytotoxicity damage } \\
\cline { 2 - 4 } Treatment & 7 DAT & 14 DAT & 21 DAT \\
\hline Paclo $(\mathrm{ppm})$ & & & \\
0 & 21 & 24 & 17 \\
20 & 16 & $16^{* * *}$ & $10^{* * *}$ \\
40 & 16 & $14^{* * *}$ & $8^{* * *}$ \\
60 & 18 & $19^{* *}$ & $11^{* * *}$ \\
Main effects & $\mathrm{NS}$ & $*$ & $* *$ \\
Bendio & & & \\
$0 \times$ & 0 & 0 & 0 \\
$1 \times$ & $2^{\text {vs }}$ & $3^{\text {vs }}$ & $1^{\text {*s }}$ \\
$2 \times$ & $18^{* * *}$ & $19^{* * *}$ & $8^{* * *}$ \\
$4 \times$ & $50^{* * *}$ & $52^{* * *}$ & $36^{* * *}$ \\
Main effects & $* * *$ & $* * *$ & $* * *$ \\
Paclo $\times$ Bendio & $\mathrm{NS}$ & $\mathrm{NS}$ & $\mathrm{NS}$ \\
\hline
\end{tabular}

${ }^{x}$ Rating on continuous scale $0=$ no damage to $100=$ severe damage.

${ }^{y}$ Single degree-of-freedom orthogonal contrasts of treatment vs. 0 ppm Paclo or $0 \times$ the recommended label rate of Bendio.

Ns, ${ }^{*}{ }^{* *}{ }^{* * *}$ Nonsignificant or significant at $P \leq 0.05$, 0.01 , or 0.001 , respectively.

Table 5. Effect of paclobutrazol on phytotoxicity ratings of salvia at 7,14 , or 21 days after treatment (DAT) with four times the recommended label rate of bendiocarb. Bendiocarb was applied $5 \mathrm{~h}$ after paclobutrazol treatments.

\begin{tabular}{lccc}
\hline \hline \multirow{2}{*}{$\begin{array}{l}\text { Paclobutrazol } \\
\text { rate (ppm) }\end{array}$} & \multicolumn{3}{c}{ Phytotoxicity damage } \\
\cline { 2 - 4 } & 7 DAT & 14 DAT & 21 DAT \\
\hline 0 & 56 & 63 & 51 \\
20 & 46 & 51 & 34 \\
40 & 48 & 41 & 26 \\
60 & 52 & 52 & 34 \\
Main effects & $*$ & $* * *$ & $* * *$ \\
Contrasts & & & \\
$\quad 0$ vs. 20 & $* *$ & $* *$ & $* * *$ \\
$\quad$ vs. 40 & $*$ & $* * *$ & $* * *$ \\
$\quad 0$ vs. 60 & Ns & $* *$ & $* * *$ \\
\hline
\end{tabular}

${ }^{2}$ Rating on continuous scale $0=$ no damage to $100=$ severe damage.

${ }_{\mathrm{NS},{ }^{*+*}, *+*}$ Nonsignificant or significant at $P \leq 0.05$, 0.01 , or 0,001 , respectively. conferred protection from $4 \times$ bendiocarb (i.e., reduced maximum phytotoxicity ratings), the date of paclobutrazol application affected the degree of protection (Fig. 1). The maximum phytotoxicity ratings for $4 \times$ bendiocarb applied to plants not treated with paclobutrazol were $>50$. Maximum protection was conferred by paclobutrazol applied 4 days before applying bendiocarb; all phytotoxicity ratings were $<20$. Paclobutrazol applied the same day as or 4 days after insecticide application still provided some protection from phytotoxicity. The lack of protection by $40 \mathrm{ppm}$ paclobutrazol applied 4 days after the insecticide application is unexplained. Growth regulation by the treatment was expected, but phytotoxicity ratings were uniformly high in subplots. Salvia plants treated with $1 \times$ bendiocarb showed less phytotoxicity than plants treated with $4 \times$ bendiocarb, but the interaction with time of application was consistent with that shown in Fig. 1 for the $4 \times$ rate (data not presented).

\section{Discussion}

Insecticide phytotoxicity can be a problem for greenhouse operators, especially bedding plant growers dealing with a wide variety of crops and cultivars. Plants sensitive to insecticides, e.g., salvia, are good test plants for establishing methods to reduce insecticide phytotoxicity. Our results demonstrate that paclobutrazol can reduce the bendiocarb phytotoxicity on a sensitive species. Previous work with salvia indicates paclobutrazol also reduced phytotoxicity from the insecticide acephate and insecticidal soap (Latimer and Oetting, 1990).

The mechanism of this protection is unknown. Paclobutrazol affects leaf expansion and increases leaf thickness by increasing palisade cell length, which produces an increase in net photosynthesis on a specific leaf area basis (Jaggard et al., 1982). Paclobutrazol increased pecan [Carya illinoinensis (Wangenh.) K. Koch] leaf thickness as well as carbohydrate and chlorophyll concentrations (Wood, 1984). Histological studies of paclobutrazol-treated Chrysanthemum leaves indicated increased leaf thickness due to an extra layer of palisade mesophyll with shorter, smaller diameter, more tightly packed cells with reduced intracellular spaces (Burrows et al., 1992).

All these morphological differences may be related to reduced insecticide phytotoxicity on salvia. The reduction of damage to salvia plants treated 8 and 4 days before insecticide treatment would support a morphological role of plant protection by paclobutrazol (Fig. 1). However, evidence is growing for a biochemical mechanism for the protestant role of plant growth regulators, such as an increase in the antioxidant activity in treated plants (Lee et al., 1992; Upadhyaya et al., 1991). The lesser, but significant, degree of protection of salvia plants treated with paclobutrazol the same day as or 4 days after insecticide treatment also supports a biochemical mechanism for plant protection. The greatest protection at 4 days before insecticide treatment may support a dual mechanism. Morphological changes are evident while the dilution of paclobutrazol in the growing tissue is less than that in the plants treated 8 days before bendiocarb application.

Identification and subsequent manipulation of cultural practices, including the use of plant growth regulators, irrigation schedules, growing temperatures, and media selection, that affect insecticide phytotoxicity can contribute to plant health management. This knowledge can enhance grower productivity

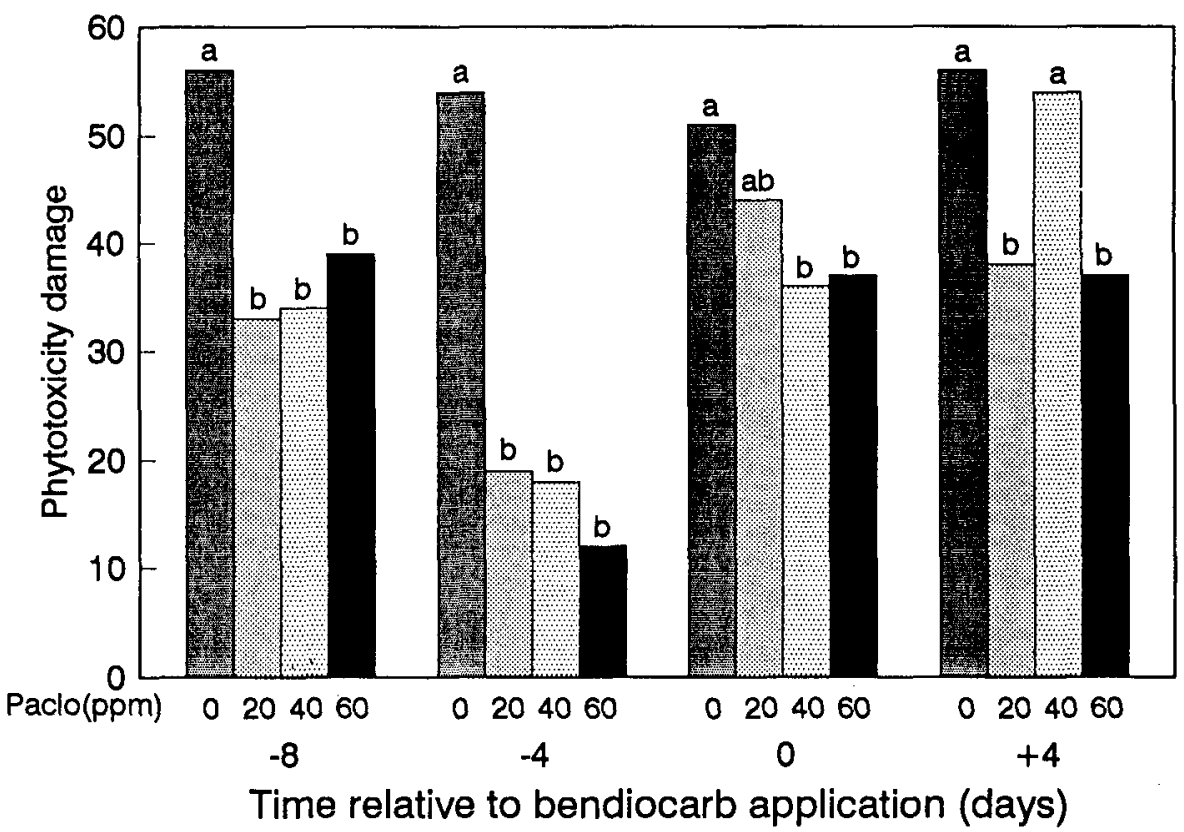

Fig. 1. Effect of four rates of paclobutrazol (Paclo) on phytotoxicity ratings of salvia plants at 7 days after treatment with four times the recommended label rate of bendiocarb, Paclobutrazol was applied at 8 and 4 days before, the same day as $(0)$, or 4 days after the bendiocarb treatment. Mean separation signified by different letters within application date were determined by single degree-of-freedom contrasts $(P \leq$ $0.05)$. 
by increasing flexibility in insecticide use and reducing plant damage, thereby improving final plant quality.

\section{Literature Cited}

Asare-Boamah, N.K. and R.A. Fletcher. 1986. Protection of bean seedlings against heat and chilling injury by triadimefon. Physiol. Plant. 67:353358.

Burrows, G.E., T.S. Boag, and W.P. Stewart. 1992. Changes in leaf, stem and root anatomy of chrysanthemum CV. Lillian Hock following paclobutrazol application. J. Plant Growth Regulat. 11:189-194.

Crocker, R.L. and B.S. Brewer. 1987, Greenhouse vs. field phytotoxicity of two formulations of chlorpyrifos on ornamental bedding plants. Proc. Southern Nurserymen's Assn. Res. Conf. 32:203-207.
Jaggard, K.W., D.K. Lawrence, and P.V. Biscoe. 1982. An understanding of crop physiology in assessing a plant growth regulator on sugar beet, p. 139-150. In: J.S. McLaren (ed.). Chemical manipulation of crop growth and development. Butterworths, London.

Latimer, J.G. and R.D. Oetting. 1990. Bonzi reduced insecticide phytotoxicity on salvia. Proc. Southern Nurserymen's Assn. Res. Conf. 35:231-234.

Lee, E.H., G.F. Kramer, R.A. Rowland, and M. Agrawal. 1992. Antioxidant and growth regulators counter the effects on $\mathrm{O}_{3}$ and $\mathrm{SO}_{2}$ in crop plants. Agr. Ecosystems \& Environ. 38:99106.

Littell, R.C., F.J. Freund, and P.C. Spector. 1991. SAS system for linear models. SAS Institute, Cary, N.C.

Little, T.M. 1985. Analysis of percentage and rating scale data. HortScience 20:642-644.
Oetting, R.D., J.G. Latimer, and K.S. Steele. 1988. Effect of potting media $\mathrm{pH}$ on insecticide phytotoxicity. Proc. Southern Nurserymen's Assn. Res. Conf. 33:139-142.

Phatak, S.C., C.A. Jaworski, and S.R. Ghate. 1985. Daminozide protects potato seedlings from metribuzin phytotoxicity. HortScience 20:690691.

Upadhyaya, A.; T.D. Davis, and R.H. Walser. 1991. Alleviation of sulfur dioxide-induced phytotoxicity in cucumber plants by uniconazole. Biochem. Physiol. Pflanzen. 187:59-65.

Wood, B.W. 1984. Influence of paclobutrazol on selected growth and chemical characteristics of young pecan seedlings. HortScience 19:837839.

York, A.C., D.L. Jordan, and R.E. Frans. 1991, Insecticides modify cotton (Gossypium hirsutum) response to clomazone. Weed Technol. 5:729735 . 